For use at 2:00 p.m., E.S.T.

Wednesday

January 16, 2013

\title{
Summary of Commentary on
}

\section{Current Economic Conditions}

By Federal Reserve District 
SUMMARY OF COMMENTARY ON CURRENT ECONOMIC CONDITIONS

BY FEDERAL RESERVE DISTRICTS

JANUARY 2013 


\section{TABLE OF CONTENTS}

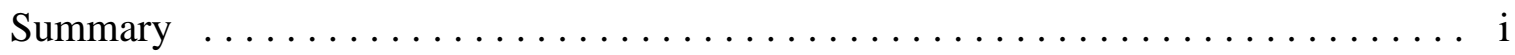

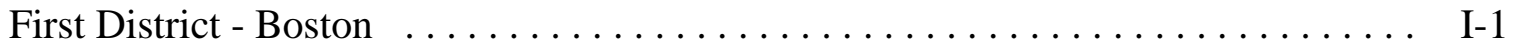

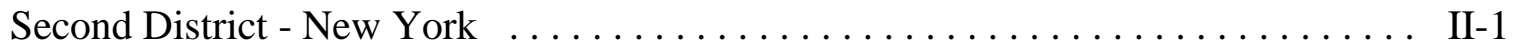

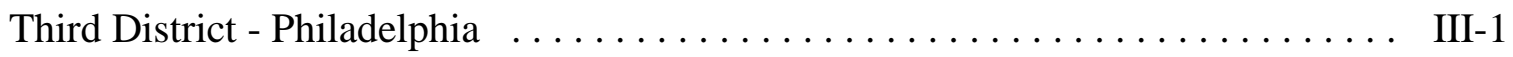

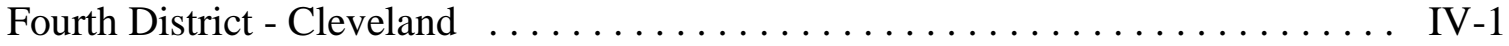

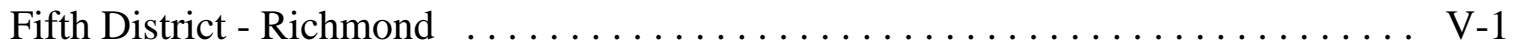

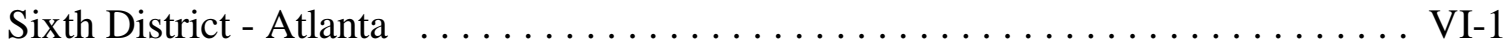

Seventh District - Chicago $\ldots \ldots \ldots \ldots \ldots \ldots \ldots \ldots \ldots \ldots \ldots \ldots \ldots$ VII-1

Eighth District - St. Louis $\ldots \ldots \ldots \ldots \ldots \ldots \ldots \ldots \ldots \ldots \ldots \ldots \ldots \ldots$ VIII-1

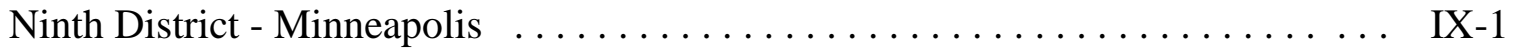

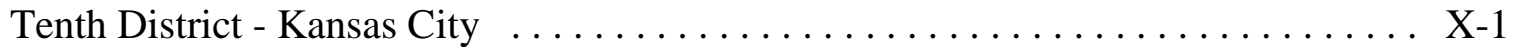

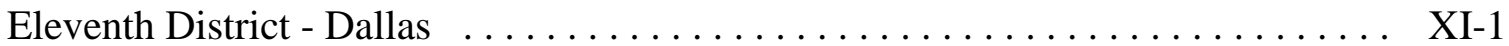

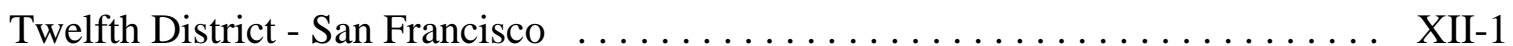




\section{SUMMARY*}

Reports from the twelve Federal Reserve Districts indicated that economic activity has expanded since the previous Beige Book report, with all twelve Districts characterizing the pace of growth as either modest or moderate. Since the previous Beige Book, activity in the New York and Philadelphia Districts rebounded from the immediate impacts of Hurricane Sandy. Growth in the Boston, Richmond, and Atlanta Districts appears to have increased slightly, while the St. Louis District reports some slowing.

All twelve districts reported some growth in consumer spending. Overall, holiday sales were reported as being modestly higher than in 2011, though sales were below expectations for contacts in many of the Districts. Auto sales were reported as steady or stronger in ten Districts. Citing concerns that consumers will spend cautiously due to ongoing fiscal uncertainty, retail contacts and auto dealers reported a slightly dimmer, though positive, outlook for future sales. Tourism activity was reported to have increased across much of the nation due to strong business and international travel, early snowfall in some ski areas, and a rebound in areas disrupted by Hurricane Sandy.

Activity among nonfinancial service sectors improved overall. Firms within the six Districts reporting on transportation services generally noted increased volumes. Manufacturing was mixed overall since the previous Beige Book; six Districts reported an expansion of activity and three reported a decrease. Among Districts reporting on their firms' near-term expectations, the manufacturing outlook remained generally optimistic; however, capital spending plans were less uniformly positive.

\footnotetext{
* Prepared at the Federal Reserve Bank of Philadelphia and based on information collected on or before January 4, 2013. This document summarizes comments received from businesses and other contacts outside the Federal Reserve and is not a commentary on the views of Federal Reserve officials.
} 
Since the previous Beige Book, real estate activity has expanded or held steady in eleven Districts for existing home sales and leasing; eight Districts for residential construction; eleven Districts for nonresidential sales and leasing; and nine Districts for nonresidential construction. Overall loan demand was steady in five Districts, rose in four, and fell in one. Credit standards were largely unchanged, except in two Districts where there were some signs of loosening. Six Districts reported improving credit quality and/or falling delinquency rates.

Although rain partially eased drought conditions for some agricultural regions in three Districts, reports of agricultural activity remained mixed. Districts reported that energy and mining sector activity was steady at high levels for most energy-related products but significantly weaker in coal production and coal-related investments.

Trends in wages, prices, and employment conditions were relatively unchanged in the Federal Reserve Districts. Input price pressures were reported to be steady overall with mixed reports for specific commodity prices in various Districts. Employment conditions were also little changed since the last report. However, hiring plans were more cautious for firms doing business in Europe or in the defense sector. Wage pressures were stable in all twelve Districts, though several Districts cited greater pressures for firms that reported difficulties finding qualified workers with specific skills.

\section{Consumer Spending and Tourism}

Since the previous Beige Book, consumer spending increased to some degree in all twelve Districts. Across the nation, holiday sales grew modestly compared with last year but came in below expectations in the New York, Cleveland, Atlanta, Chicago, and San Francisco Districts. Boston reported continued strong demand for clothing, shoes, 
and furniture, and San Francisco reported robust online sales. A major retail chain in New York indicated that sales picked up in early January. Retail sales were flat in Richmond except for gains in food and auto sales. Expectations for future sales were positive but mild, particularly in Philadelphia, Kansas City, and Dallas where contacts cited the impact of fiscal cliff uncertainty on consumer spending.

Reports of auto sales were steady to stronger in ten Districts. Richmond, Atlanta, and San Francisco noted strong sales. New York and Dallas cited mixed sales that were generally positive, while auto sales in Kansas City slowed but remained higher than a year ago. Some dealers in the Chicago and Kansas City Districts reported high levels of inventory. Contacts in Philadelphia, Cleveland, Kansas City, and Dallas expect consumers to react to ongoing fiscal uncertainty, thus dimming a positive outlook for future sales. Chicago auto dealers were more upbeat, expecting stronger new car sales due to pent-up consumer demand, easing credit conditions, and rising used vehicle prices.

Tourism held steady or grew in all but one of eight reporting Districts. Coastal activity had fallen in the immediate aftermath of Hurricane Sandy throughout most of the New York and Philadelphia Districts but has rebounded in all but the hardest hit areas. Boston, Atlanta, and San Francisco reported strong tourism in their Districts, with Boston and Atlanta citing business and international travel as strong contributors. Winter tourism activity in the Minneapolis District was strong in areas with snow, while Richmond reported normal winter activity in its District.

\section{Nonfinancial Services}

Overall, nonfinancial services have grown modestly since the previous Beige Book. Businesses in the New York and Philadelphia Districts recovered from the 
disruption of Hurricane Sandy. The Boston, Minneapolis, and San Francisco Districts reported positive growth among various service sectors, while the Richmond District reported stable to stronger demand for service firms. Boston reported strong demand for some health-care IT services and drug impact research, while San Francisco noted relatively weak demand for health-care services. Staffing firms in the Dallas District reported steady to slightly softened demand. Respondents remained optimistic about growth over the near-term in the Boston, New York, Philadelphia, Minneapolis, and Dallas Districts.

Transportation services were generally positive among the six Districts that reported. Freight transport shipping volume improved in the Cleveland District due to rising demand from the retail sector and areas affected by Hurricane Sandy. Atlanta reported increases in trucking tonnage and total railroad carloads, but low river levels caused delays in Mississippi River traffic. Reports from transportation services in the Dallas District were mixed, and most firms expect weak growth in the near-term. Trucking firms in the Richmond District reported a flattening in revenues; however, the District's port activity was boosted by ships diverted by Hurricane Sandy.

\section{Manufacturing}

Reports of manufacturing activity were mixed overall, with six Districts growing since the last Beige Book, three Distracts contracting, and two Districts reporting little or no change. Firms in the Boston and Chicago Districts reported continued expansion of activity at modest and moderate rates of growth, respectively. Overall activity once again appeared to expand in the San Francisco District, although it was mixed across sectors. Gains in the aerospace and chemical sectors contributed to growth in the Boston and San 
Francisco Districts, as well as in the Dallas District. Manufacturing in the Chicago District grew with contributions from the auto and housing-related sectors. Manufacturing continued to expand, but at a more modest pace, in the Richmond District. Several firms cited falling export demand, especially from Europe.

In contrast to slight declines in the past Beige Book, firms in the Philadelphia and Minneapolis Districts reported slightly increased manufacturing activity. As in other Districts, product flowing into supply channels for auto production and housing construction contributed to Philadelphia's gains. Prior trends continued as firms in the New York District experienced little or no growth, except for the revenues of firms in the New York City area that recovered after Hurricane Sandy disruptions. Reports continued to be mixed among sectors in the Dallas District.

Manufacturing activity within the Cleveland and Atlanta Districts, and reported plans in the St. Louis District, declined somewhat - a trend reversal from the prior Beige Book. Contributing to the declines were steel and auto producers in Cleveland and makers of HVAC equipment, electric components, food, and automobile parts in St. Louis. Despite production gains in electrical equipment, appliances, and components, more pronounced contractions within the broad nondurable goods sector led to a continuation of declining activity in the Kansas City District.

Manufacturing firms' expectations of future activity were generally optimistic in the New York, Philadelphia, Atlanta, Minneapolis, and Kansas City Districts; the level of optimism has significantly increased in the Philadelphia and Atlanta Districts since the previous Beige Book. Contacts in the Chicago District expect vehicle production to expand in 2013, while reports of activity from manufacturers in the St. Louis District 
have been negative on net. Boston District firms reported that capital spending was slow, except for select growth sectors. Capital spending was on track in the Cleveland District and was slowly increasing in the Chicago District. Looking ahead, Philadelphia District firms have significantly increased their capital spending plans, while the outlook in the Minneapolis District was reported as flat. In the Cleveland District, more contacts plan to reduce outlays than expand capacity.

\section{Real Estate and Construction}

Existing residential real estate activity expanded in all Districts that reported; growth rates were described as moderate or strong in nine Districts. Contacts in the Boston District attributed their strong sales growth to low interest rates, affordable prices, and rising rents. All Districts reporting on price levels saw increases; New York and Chicago reported only very minor increases. The five Districts that reported on housing inventories all reported falling levels. New residential construction (including repairs) expanded in all but one District of those Districts that reported. Contacts in the Kansas City District reported that increased lumber and drywall costs limited construction, causing a slight decline this period. Hurricane Sandy disrupted construction activity initially in New York, but this has since led to increased work for subcontractors on repairs and reconstruction.

Though a little weaker than residential real estate, reports on sales and leasing of nonresidential real estate are still mostly positive - described as modest on average. The Boston District reported a drop in leasing beyond normal seasonal trends; contacts cited fiscal cliff uncertainty as a factor. Minneapolis and Kansas City reported increased demand and tightening commercial real estate markets. Philadelphia, St. Louis, and 
Dallas all reported more modest increases in nonresidential real estate activity.

Nonresidential construction is weaker than residential, with only slight to modest growth.

The Boston District reported that demand for commercial real estate loans appears to be softening and that the pipeline for new construction projects has diminished significantly since the last report. Dallas reported that construction was expected to pick up in the commercial real estate sector in 2013.

\section{Banking and Finance}

Overall, loan demand was largely unchanged in the Philadelphia, Cleveland, Richmond, Kansas City, and San Francisco Districts, with most of these Districts reporting a continuation of slight to moderate growth in total volume. The New York, Atlanta, Chicago, and Dallas Districts reported stronger demand than previously, while the St. Louis District reported a slight decline. Some increased lending in Philadelphia, Chicago, and Dallas was driven by businesses taking out loans for special year-end purposes such as tax planning and dividend payments. Cleveland, Atlanta, Chicago, Dallas, and San Francisco all reported strong auto lending. Demand for residential mortgages improved in Cleveland, Atlanta, Chicago, Kansas City, Dallas, and San Francisco. Commercial real estate lending was cited as a particular bright spot by New York, Cleveland, Kansas City, and Dallas. However, lenders in San Francisco remained reluctant to lend to real estate investors outside of the multifamily residential sector. San Francisco also reported a slight slowdown in IPO, venture capital, and private equity activity in that District's technology sector.

Banks in the New York, Philadelphia, Cleveland, Chicago, Kansas City, and San Francisco Districts reported improvements in asset quality. Lenders were described as 
competing aggressively for highly qualified borrowers in Philadelphia, Richmond, Atlanta, and San Francisco. In Atlanta, this stiff competition may be leading to loosening credit standards, as there was some indication that banks were more willing to increase their tolerance for risk. Chicago banks also reported some loosening of standards. On the other hand, lending standards remained largely unchanged in New York, Cleveland, and Kansas City.

\section{Agriculture and Natural Resources}

Reports of agricultural activity were mixed, although rain and mild temperatures delivered some relief from drought conditions to parts of the Richmond, Atlanta, and Chicago Districts. Low water levels along the Mississippi River also hampered transport for some contacts in the Chicago and Kansas City Districts. Despite the drought, some contacts in these Districts reported that farm income remained high with adequate crop insurance and historically high prices. Producers in the Kansas City and Dallas Districts expect ongoing dry conditions to hurt the winter wheat crop.

Activity in the energy sector had mixed reports. Production of oil and natural gas held steady at high - sometimes record - levels in the Cleveland, Richmond, Minneapolis, and Dallas Districts. San Francisco reported that activity expanded to historic levels. Contacts in the Cleveland District reported that shale gas activity grew at a robust pace. In contrast, coal production has declined in the Cleveland, Richmond, Chicago, St. Louis, and Kansas City Districts since the previous Beige Book. Firms in the Atlanta District continue to plan investments, ranging from reserve development to increased refining and petrochemical operations to new pipeline infrastructure. 


\section{Employment, Wages, and Prices}

Labor market conditions remained mostly unchanged in all Districts. The Boston, Richmond, Atlanta, Chicago, Kansas City, and San Francisco Districts all reported delayed hiring, often in defense manufacturing, due to fiscal cliff uncertainties.

Companies in the Chicago District with trade or investment exposures to Europe reduced their hiring plans as well. Chicago reported that manufacturers are choosing to cut hours instead of reducing head count in expectation of production rebounds in 2013. Atlanta and Kansas City cited health-care policy changes and costs as another cause for minimal hiring. On the other hand, the New York, Atlanta, Minneapolis, and Dallas Districts saw the labor market firming modestly. Finally, contacts in several Districts reported difficulties finding qualified workers in some specialized fields, such as skilled manufacturing, energy, and IT.

For those Districts that reported, wage pressures have been stable since the previous Beige Book and were most frequently described as contained or subdued. The San Francisco District reported modest wage pressures that were held down by an abundance of workers. The Richmond, Chicago, and Minneapolis Districts characterized wage growth as moderate. Specifically, business contacts in the Minneapolis District expected to increase wages 2 to 3 percent in 2013, while oil drilling companies in North Dakota and Montana expected higher increases. Several Districts reported wage pressures in sectors experiencing labor shortages, such as energy and IT. The New York and Chicago Districts reported higher year-end bonuses ahead of anticipated tax increases in 2013. 
Overall, input price pressures appear to be stable. The Boston, Philadelphia, Cleveland, Richmond, Minneapolis, Dallas, and San Francisco Districts reported steady input prices, while Chicago reported decreasing raw materials prices. The New York, Atlanta, and Kansas City Districts characterized input prices as slightly increasing; price pressures in these Districts were passed through to consumers somewhat in the form of higher finished goods prices. However, Chicago noted that businesses were unable to fully pass on meat and milk price increases to consumers. The Philadelphia, Cleveland, Chicago, Kansas City, and San Francisco Districts all cited rising prices for constructionrelated materials. Specifically, a Philadelphia builder noted that over the past 90 days these rising prices added about 3 percent to the cost of a new home. 


\section{FIRST DISTRICT - BOSTON}

Economic activity in the First District continues to grow modestly, according to business contacts. Most retailers and the tourism industry cite year-over-year increases in demand. Aside from some firms with industry-specific or customer-specific issues, First District manufacturers also report growth in sales from a year ago. Similarly, consulting and advertising firms are ahead of a year earlier, although a couple of companies with fast growth over the last few years have recently seen business level off. Commercial real estate contacts are somewhat downbeat; office leasing is slow and demand for commercial real estate loans and pipelines for commercial construction activity are weaker than in recent reports. Residential real estate markets continue to recover, with both sales and prices in November above year-earlier levels. In all sectors, most respondents are holding their selling prices level. Contacts say their hiring depends on demand growth; as a result, most firms are doing little to no hiring, but some firms are expanding headcounts substantially. Notwithstanding ongoing concerns with uncertainty, contacts generally expect continued modest growth in 2013.

\section{Retail and Tourism}

One contact reports a small single-digit year-over-year decrease in December sales while the others cite increases ranging from near zero to 7 percent. Demand remains strong for clothing, shoes, and furniture. Responding retail firms expect to hold their selling prices steady based on an absence of price increases at the wholesale level. These contacts anticipate that 2013 will be characterized by low singledigit growth in sales.

The tourism industry ended 2012:Q4 on a high note, establishing new records for hotel room occupancy rates and revenues. Strong domestic and international corporate business travel and international leisure travel account for much of this performance. Restaurants saw less spending on corporate entertaining and end-of-year holiday events. Advance hotel booking data indicate that the strong trend in business travel will continue, leading to an expectation that occupancy rates will hold level in 2013 compared to the high benchmark established in 2012.

\section{Manufacturing and Related Services}

Manufacturing in New England continues to expand at a modest pace according to First District contacts. Of 11 responding firms, seven report higher sales in the fourth quarter than in the same period a year earlier, although in some cases the gains are quite modest. Two contacts in the semiconductor industry continue to report a cyclical downturn in their business. A contact in aerospace says that sales of parts for new airplanes are extremely strong but depressed conditions in the aftermarket have spread from the United States to Europe. A contact in the chemical industry says that while sales in pounds fell, the pricing picture improved so much that sales in dollars are up. Sales of frozen fish continue to be weak. The "fiscal cliff" was an explicit problem for a computer firm that sells almost exclusively to Defense Department customers who are worried about sequestration. 
Only five of the 11 respondents report significant hiring. Firms with rapidly growing sales are hiring, but firms in slow-growth industries are not. A biotech firm with 3,500 U.S. employees plans to add another 1,000 over the coming year, about half domestically. The computer supplier with customers dependent on defense spending cut its staffing by 10 percent to 15 percent over the period from June to September. A contact in the chemical industry reports both good and bad news about the labor market. On one hand, he says that for the first time since the crisis began, workers are voluntarily leaving to take new jobs. The bad news is that he is having great difficulty filling low-skill jobs. He says that drug test fails are much more common than in the past; in addition, a large number of workers quit almost immediately after taking the job. The contact speculates that both of these hiring problems may result from behaviors developed during extended periods of unemployment.

As with employment, capital spending is generally slow except for firms in growth industries, with four firms reporting increases and four reporting decreases in spending. One diversified manufacturer of parts for the aerospace and auto industries reports that business units within the firm failed to spend their planned capex allocations in 2012.

The outlook continues to be uncertain for most of our contacts. Only one firm, the defense supplier, cites the fiscal cliff as a serious problem and even they expect some resolution in the new year.

\section{Selected Business Services}

Consulting and advertising contacts in the First District report generally positive results for the

fourth quarter. Several contacts report modest growth, while two contacts - whose firms have experienced rapid growth over the past two years - experienced a leveling off. Marketing and advertising contacts report a slight uptick during the fourth quarter and are confident that business conditions have finally stabilized after the recession, which hit them with a lag. Two contacts with exposure to health care note robust demand for services related to health-care IT implementation and drug-impacts research. At the same time, firms focused on the pharmaceutical industry have experienced slow growth, although one contact expects that pharmaceuticals will start to emerge from its rough spell in 2013. Economic consulting remains strong because of high levels of complex high-stakes litigation; management and strategy consulting contacts report flat business conditions as clients uncertain about fiscal policy and the macroeconomy remain reluctant to invest in consulting services.

Contacts report little to no cost increases and are keeping their prices relatively unchanged. One exception is an advertising firm where health insurance costs rose 12 percent in 2012. Some contacts report no hiring, consistent with a lack of demand growth, while others report net hiring in the low single digits. Plans for future hiring are modest, with contacts generally expecting zero to low single-digit workforce increases in 2013.

Most contacts expect growth to pick up in 2013, with the exception of a government contractor, who is too uncertain about the future of fiscal policy to offer any forecast. No one expects another 
recession and overall they express a sense of cautious optimism.

\section{Commercial Real Estate}

Across most of the First District, leasing activity in the final weeks of 2012 is described as very light, driven by a combination of seasonal factors and uncertainty stemming from fiscal cliff negotiations. However, a Portland contact notes an uptick in leasing activity in that city in December, especially in the warehouse sector, although office fundamentals remain flat amid slow employment growth. Boston's warehouse market improved as well, while the city's office vacancy rate remains high —also attributed to slow employment growth — and the trend toward office downsizing persists. In Hartford, the fate of large downtown properties that experienced foreclosure in 2012 remains uncertain; a key question is whether current owners will reinvest in the properties or resell them as is. Demand for commercial real estate loans in the region appears to be softening, while the pipeline of new construction projects in Boston has diminished significantly since the last report.

Most contacts in the region are cautiously optimistic that commercial real estate fundamentals will improve in 2013. However, growth expectations remain very modest and some contacts note downside risks to growth from pending fiscal contraction and ongoing political uncertainty, even taking into account the recently-enacted federal tax deal.

\section{Residential Real Estate}

Across the First District, contacts report strong year-over-year growth in sales for November in both single-family home and condominium markets. Similar to previous reports, contacts attribute continued growth in sales to low interest rates, affordable prices, and rising rents. Contacts say that buyers have become more confident about purchasing a home as economic conditions continue to improve. As buyer activity increased, inventory levels fell throughout the region. Contacts argue that declining inventory levels have now translated into higher prices in most areas. The median sale price of homes rose year-over-year across the First District, with some states experiencing significant increases.

In terms of outlooks for the coming year, contacts continue to feel positive about improvements in home values and strong sales. Significant year-over-year growth in sales is expected for the most of 2013, although a warm winter last year coupled with a potentially harsher winter this year may soften year-over-year growth in the coming months. In Massachusetts and the Greater Boston area, contacts express concern that dwindling inventory levels will discourage buyers and even potentially deter some sellers who would like to purchase a replacement home before listing their current one; at the same time, they express worry about prices appreciating too quickly, but say they are not concerned with ongoing moderate price appreciation. Notwithstanding these potential concerns, contacts across the region are generally very optimistic about the strength of the housing market in 2013. 


\section{SECOND DISTRICT--NEW YORK}

Economic activity in the Second District has shown signs of rebounding since the last report, as widespread disruptions from Superstorm Sandy largely dissipated. On balance, the labor market firmed, with manufacturers reporting flat employment but non-manufacturing contacts indicating some pickup in hiring. Manufacturers and other firms report more widespread price hikes than in recent months, while retail prices were steady to up moderately. Retailers report that holiday-season sales were steady to somewhat higher than this time last year but slightly below plan. Auto sales in upstate New York were mixed but generally strong in November and December. Tourism activity slumped in November, in the aftermath of Sandy, but rebounded somewhat in New York City in December. Both residential and commercial real estate markets were generally steady since the last report. Finally, bankers report a pickup in demand for commercial mortgages but steady demand on other types of loans; they also report no change in credit standards, narrowing loan spreads, and widespread decreases in delinquency rates.

\section{Consumer Spending}

Holiday season sales were up modestly from last year but came in slightly below plan. A trade association survey of retailers across New York State indicates that sales were disappointing in the days leading up to Christmas as well as in the days after. A major retail chain indicates that sales were below plan in November and December but picked up fairly dramatically in early January. Retail contacts in upstate New York report that sales were flat to up compared to a year earlier. Retailers attribute the weaker than expected holiday sales to a combination of online shopping, mild weather, fiscal cliff concerns, and, in some parts of the region, slow insurance payouts to those affected by Sandy. Retail prices were reported to be steady or up moderately.

Buffalo-area auto dealers indicate that vehicle sales picked up in November but were expected to be flat to slightly lower than a year earlier in December. However, Rochester-area dealers report strong sales for both months to end 2012. Tourism activity slumped in the immediate 
aftermath of Sandy. Even hotels in the Albany area were reportedly affected by the storm, as widespread meeting and conference cancellations pushed down hotel occupancy rates in November. In New York City, Broadway theaters report that attendance and revenues rebounded after a deep post-Sandy slump in the first half of November. Still, December attendance was down 5 to10 percent from a year earlier, while revenues were little changed. Finally, consumer confidence in the region weakened at year end. The Conference Board's survey of residents of the Middle Atlantic states (NY, $\mathrm{NJ}, \mathrm{Pa}$ ) showed confidence falling to its lowest level in more than a year, while Siena College's survey of New York State residents indicated a modest decline.

\section{Construction and Real Estate}

Residential real estate markets in the District were generally steady since the last report, with the storm having little discernible effect on the overall market. New York City's rental market appears to have lost some momentum during the final two months of 2012, as rents in Manhattan and Brooklyn retreated and were up only slightly from a year earlier. The inventory of available rental apartments, however, remained low in late 2012. Apartment sales activity in New York City was robust in the fourth quarter - particularly in Manhattan. A major appraisal firm attributes some of the high sales volume to looming tax changes and notes that there has been a flood of appraisal requests for tax-related financial planning. Prices are reported to be flat to up slightly. In contrast, an overhang of inventory has kept prices from rising in northern New Jersey and Long Island. Sandy disrupted construction activity in late 2012, though a contact in the homebuilding industry notes that construction sub-contractors are getting a great deal of work from storm-related repairs and reconstruction during a typically slow season.

Office markets were relatively stable in the final months of 2012. A commercial real estate contact reports that the recovery from Sandy in Lower Manhattan has been slow, as a number of buildings in the flood zone remained out of service at year end. More broadly, leasing and sales activity across Manhattan were sluggish in November but picked up in December. Vacancy rates 
have been steady, while asking rents have edged up, led by brisk gains in Midtown South. Strong demand from the new media and advertising sectors and some pickup from legal services have offset weak demand from the financial sector. Elsewhere in the region, vacancy rates were little changed in the fourth quarter, though asking rents fell noticeably in northern New Jersey.

\section{Other Business Activity}

Contacts in the manufacturing sector continue to report little or no growth in activity though they remain mildly optimistic about the near-term outlook. Non-manufacturing contacts report some improvement in business conditions and have grown increasingly optimistic about prospects for 2013. New York City area firms — both manufacturing firms and non-manufacturing firms — say that Sandy adversely affected revenues in November but that business was seen to be back on track in December.

On balance, labor market conditions firmed in late 2012. While business contacts in the manufacturing sector report little or no change in employment, contacts in other sectors note some pickup in hiring. A major New York City employment agency specializing in office jobs said that while it is difficult to assess the labor market during the holiday season some continued softness in labor market conditions is apparent. In particular, financial sector hiring has remained sluggish, but year-end bonuses are expected to be up moderately from a year ago. Much of the bonus pay typically distributed in January was reportedly paid out in December in advance of higher tax rates.

\section{Financial Developments}

Small- to medium-sized banks report no change in demand for all loan types except commercial mortgages, where loan demand increased. Bankers report little change in demand for refinancing. The vast majority of respondents continue to report that credit standards were unchanged across all categories. Respondents indicate a decrease in spreads of loan rates over the costs of funds for all loan categories-particularly in residential mortgages, where nearly three in five bankers report lower spreads. Respondents also indicate a decrease in average deposit rates, on balance. 
Finally, bankers note declining delinquency rates in all loan categories - most notably in commercial mortgages, where well over half of those surveyed report lower delinquencies. 


\section{THIRD DISTRICT - PHILADELPHIA}

Aggregate business activity in the Third District has resumed the modest pace of growth that was evident prior to the disruption by Hurricane Sandy during the previous Beige Book period. In particular, general retail sales, general services, and commercial real estate leasing recovered from temporarily mild growth rates to resume their previously modest growth rates. Sales of new and used autos accelerated to a moderate rate of growth, and residential real estate sales maintained a strong year-over-year growth rate (from a relatively low base). Mild rates of growth are once again evident in manufacturing, staffing services, transportation services, and construction after many sectors suffered storm-related disruptions. Lending volumes at Third District banks also continued to experience slight growth, and credit quality has continued to improve. Overall, beach-going tourist areas are experiencing a typical slow season; however, some storm-damaged areas have lost significant business while some areas that escaped the damage are doing well. General price levels, as well as wages and home prices, were reported to have increased slightly overall. This remains similar to the last Beige Book period, except for home prices, which had remained flat overall.

The overall outlook for at least modest growth is considerably more optimistic relative to the views expressed in the last Beige Book. Contacts reported underlying strength in many sectors and expressed relief that part of the fiscal cliff dilemma has been resolved. Contacts from virtually all sectors reported greater expectations of future growth than during our last survey period. Plans for future hiring were also significantly more expansive. Most contacts continued to express concerns over the impact from the recent payroll tax increase and the remaining potential budget cuts that might reduce demand.

Manufacturing. Since the last Beige Book, Third District manufacturers have reported that orders and shipments have recovered to a pace of slight growth. The mild pace can be partially attributed to seasonal trends. Comments from contacts focused primarily on small upticks, new product demand, and emerging markets, rather than on disappointing orders. Makers of food products, lumber and wood products, primary metals, fabricated metal products, and instruments have reported gains since the last Beige Book. Lower activity was reported by makers of industrial machinery and electronic equipment.

Optimism among Third District manufacturers that business conditions will improve during the next six months has rebounded strongly since the last Beige Book and is evident across nearly all sectors. Firms have also significantly raised their overall expectations of future hiring and their plans for capital spending since the last Beige Book.

Retail. Third District retail sales recovered to a modest pace of growth for the holiday shopping season after the disruptions of Hurricane Sandy, according to retail contacts. Sales reports were mixed for mid-market department stores and some home furnishing stores, which 
reported moderate early holiday sales gains followed by a lull, with slight declines from the prior year. High-end department stores, family apparel stores, and outlet stores reported modest or moderate year-over-year sales throughout the holiday period. Some substantial mall tenants posted strong double-digit sales growth. Until final sales are tallied, retail contacts relied on other early indicators to suggest that the final days of the holiday shopping season had grown modestly, or better. Traditional mall retailers continued to draw shoppers with promotions, while outlet stores used fewer promotions than in prior years. Shopper surveys revealed concern over the consumers' future paychecks from the pending fiscal cliff negotiations.

Auto sales finished the year at a moderate pace of growth - combining the sector's slower pre-storm pace with a bump up for replacement of cars damaged by the storm. In particular, New Jersey dealers reported strong double-digit December sales, capping a third consecutive year of sales growth. The outlook among dealers remains positive; however, prospects for 2013 are not as strong as they were for 2012. "Consumers will feel a pinch" from the payroll tax increase and continued uncertainty about possible budget cuts.

Finance. Overall, loan volumes have continued to grow at a slight pace across Third District financial firms since the previous Beige Book. A flurry of year-end business lending kept banks busy facilitating tax-oriented business decisions involving sales and liquidations, mergers and acquisitions, accelerated depreciation, and dividend payouts. Home mortgage refinancing rates continued to remain high. In describing their competition as very aggressive, lenders expressed awareness of some potential portfolio risk, even while the credit quality of their borrowers continued to improve. Generally, financial institutions are expecting growth to continue, if not improve.

Real Estate and Construction. Residential builders reported one final surge of contract activity in November and then a downswing in December to conclude with slight year-over-year growth for the period. Despite facing erratic swings in demand through the year, our contacts reported very strong year-over-year growth for the entire year, which is more indicative of their own gains in market share than of the sector overall. Residential brokers reported robust yearover-year sales growth in November, with steady year-end momentum. As with new home construction, existing home sales are growing from a low base. Builders and, to a greater extent, brokers are optimistic that recent growth will be sustained in 2013. As with other sectors, contacts expressed concern that the fiscal cliff negotiations had been extended into their important first quarter.

Nonresidential real estate contacts reported renewed modest growth in overall leasing activity and continued slight growth in construction. Leasing activity finished the year with sustained double-digit growth. Notably, in the fourth quarter, contacts began "to see a reemergence of leasing demand in lagging submarkets" (in the Greater Philadelphia metro area), including southern New Jersey. Stronger employment growth of professional services is credited 
with much of the demand; however, that demand is partially offset, as existing firms are consolidating and adjusting to more efficient overall office spaces with smaller square footage per person. New construction of large industrial/warehouse space is planned in 2013 in the Harrisburg-Lehigh Valley corridor on the heels of similar spaces built this year; no such construction is anticipated in the southern New Jersey market area. New apartment/condominium projects continue to emerge throughout the Greater Philadelphia region, especially in Center City. Nonresidential real estate contacts retain an outlook of slow, steady growth.

Services. Third District service-sector firms have resumed a more modest pace of growth since the last Beige Book, according to contacts in various sectors. Tourist areas along the Delaware and New Jersey shores are in various stages of recovery from Hurricane Sandy. Atlantic City casinos reported significantly lower revenues in November (as much as \$55 million) compared with 2011. Businesses and rental housing that serve the central and northern Jersey Shore communities continued to lose some of the money they would have earned in the low season. Southern New Jersey and Delaware beach communities are largely intact and operating normally. A Delaware beach hotel owner reported a strong December finish to the year, which was partly due to an extra holiday weekend. District staffing firms reported a mild pace of growth at year's end - an improvement after the storm disruptions. Staffing contacts expect moderate growth in 2013 but are watching their clients' reactions to the serial fiscal cliff decisions. Defense-related firms received no relief from the uncertainty of budget cuts that has held their business plans in stasis for the past year. Overall, service-sector firms expressed more confidence in their expectations for growth in the near future.

Prices and Wages. Overall, price levels continued to increase slightly, similar to the previous Beige Book. Cost factors among manufacturing firms held steady, while the prices they received rose a little. Tighter auto inventories generate a price environment that favors auto dealers over their customers. Homebuilders noted that rising commodity prices had added about 3 percent to the cost of a new home in the past 90 days. In addition, roofing and siding contractors have lost crews to the Jersey Shore repairs. Real estate contacts continued to report that house prices are firming up and that houses in some markets are receiving multiple offers. Rents are rising in most segments of the Philadelphia central business district market and for industrial space along the corridor from Carlisle, PA, to the Lehigh Valley. In other segments and geographies, rents are flat or still falling. Contacts from all sectors continued to report that wages rose only a little, if at all. After a good year, two homebuilders reported issuing the first pay raises to their staffs in several years. Contacts did report strong growth in unemployment compensation and workers' compensation costs. 


\section{FOURTH DISTRICT - CLEVELAND}

Business activity in the Fourth District expanded at a modest pace during the past six weeks. Many of our contacts reported that their outlook for the new year is uncertain due to unresolved fiscal policy matters. Manufacturing orders and production were mainly flat or down slightly. Residential and nonresidential construction activity rose, with particular strength noted in the multi-family segment. On balance, retailers described the holiday shopping season as solid. Sales of new and used motor vehicles increased on a year-over-year basis. Shale gas activity continued at a robust pace, though coal production trended lower. The slowdown in freight transport volume seen in September and October has abated. Demand for business credit flattened out, whereas credit use by consumers picked up.

Hiring was sluggish across industry sectors. Staffing-firm representatives saw little change in the number of job openings and placements during the past six weeks. Vacancies were found primarily in manufacturing and healthcare. Wage pressures are contained. Input prices were stable, apart from increases in construction materials.

Manufacturing. Reports from District factories indicated that new orders and production were flat or down slightly during the past six weeks. Companies seeing increases were largely suppliers to the motor vehicle and energy industries. Compared to a year ago, production activity was mixed. Steel producers and service centers described shipping volume as lower relative to levels seen in the third quarter. Many of our contacts expect a slight weakening in business activity during the next few months due to seasonal factors and uncertainty surrounding the outcome of fiscal policy issues. Auto production at District plants showed a moderate decline during November on a month-over-month basis. Relative to prior year levels, production was largely higher, especially for foreign nameplates.

Inventories are being reduced to become more aligned with demand. Manufacturers noted that capacity utilization has fallen in recent weeks; however, rates were within or slightly below their normal range. Capital spending was largely on track for 2012. About one-third of our contacts plan on cutting back capital outlays during this year, and few producers anticipate expanding capacity. Raw material prices were either flat or trended lower, while finished goods prices held steady. On balance, manufacturing payrolls were little changed. Less than half of our contacts expect to hire new workers during 2013. Wage pressures are contained, and rising health insurance premiums remain a challenge.

Real Estate. Home builders reported that the upturn in sales of new single-family homes continued into December. Although a seasonal slowdown is expected, builders expressed confidence that sales will pick up again in the spring. Contracts were found mainly in the midto higher-price-point categories. The number of single and multi-family housing starts in December was significantly above year-ago levels. List prices of new homes are increasing, which was attributed to shrinking inventories and rising construction costs. Builders have cut 
back on discounting. Tight lending standards are still seen as restraining the effect of low interest rates for builders and home buyers. Multi-family developments are expected to be the driving force behind new housing construction during the next one to two years.

Nonresidential contractors reported that business activity grew across market segments and was better than a year ago. Nonetheless, margins are still tight. Although inquiries are down, which is typical for this time of year, builders are satisfied with their backlogs going into 2013. Project financing is available, but it is very time consuming to close a deal. As a result, some developers are turning away from banks and looking more to private lenders. Our contacts are optimistic about near-term activity due to customers wanting to complete must-do projects, such as maintenance or production consolidation. However, there is a heightened level of uncertainly about the medium to long term. A general contractor reported that his customers are postponing the design phase of some of their projects. Other builders expect a slowing in health care construction, as providers evaluate the implementation of recently enacted laws.

Residential and nonresidential builders reported higher prices for drywall and lumber, due to rising demand and a declining supply base. Contractors anticipate widespread price increases for building materials during the first quarter of 2013. General contractors and subcontractors expect to increase their payrolls at a modest pace this year. There is concern about the availability of highly skilled trade workers and back-office personnel, and the potential impact a shortage of either could have on wage pressures.

Consumer Spending. Reports on the holiday shopping season were generally solid. Most retailers were encouraged by results during the Thanksgiving weekend, and a majority said that sales during this holiday season were above those of a year ago. However, some contacts reported that sales figures fell below expectations for the entire season. Increased volume was seen particularly in electronics and apparel. Sales for the first quarter of the new year are expected to trend higher relative to prior-year levels. Vendor and shelf prices held steady. Capital spending remains on target. A majority of our contacts reported that they plan to increase outlays slightly during 2013, particularly for warehousing, store improvements, and ecommerce. Little new hiring is anticipated, except for staffing new stores.

Year-to-date sales of new motor vehicles showed a moderate increase during November compared to the same time period a year ago. Dealers reported that purchases of fuel-efficient cars, including hybrids and compact SUVs, are doing well. New-vehicle inventories were described as adequate to strong. A seasonal slowdown in sales is expected during January and February. Several dealers cited uncertainty over the resolution of fiscal policy issues as a factor that may affect auto sales in upcoming months. Year-to-date sales of used vehicles increased slightly during November, though inventories are still tight. Leasing continued to trend slightly higher, which should help to replenish the used-vehicle inventory by mid-2013. One dealer noted that the balance between leasing and traditional financing has returned to normal. Some of 
our contacts reported that their employment level is lower than prior to the recession, and most do not expect to increase payrolls during the next 6 to 12 months.

Banking. Demand for business credit was steady or down slightly since our last report. Some contacts cited a rise in the number of applications for commercial real estate loans and refinancings, but on balance, demand was little changed across sectors and product categories. Several bankers noted that their loan-to-deposit ratio was much lower than desired. On the consumer side, reports indicated an increase in drawdowns on home equity lines of credit and rising credit card receivables, which were attributed to holiday shopping. A few bankers saw an increase in auto loans. Activity was strong in the residential mortgage market, with a large majority of applicants looking to refinance. Delinquency rates held steady or declined across consumer and commercial loan categories. Core deposits grew, with an ongoing transition from time-deposit to transaction accounts. Little change in banking payrolls is expected in the near term.

Energy. Conventional oil and natural gas production was stable during the past couple of months. Shale gas activity continued at a robust pace: in West Virginia, well output at the end of 2011 was up 138 percent from the prior year, and during the first six months of 2012, well output across Pennsylvania rose by 42 percent compared to the previous 6 months. In eastern Ohio, 187 wells have been drilled in the Utica shale in the past year, with 44 currently producing. Coal production for 2013 is expected to be flat relative to 2012 levels. Demand for thermal coal increased slightly due to colder weather and a slowdown in switching from coal to gas by electric utilities. Demand for metallurgical coal in the U.S. held steady, but declined from offshore customers, particularly those in Europe. Falling prices for metallurgical coal have leveled off, while steam-coal prices were mixed. Capital expenditures by conventional drillers and coal producers are expected to decline during the first six months of 2013. Production equipment and material prices were flat across most categories. Apart from shale gas companies, little hiring is anticipated during the next 6 to 12 months.

Freight Transportation. Reports on freight transport indicate that shipping volume has improved since the start of November after an unexpected drop-off during the prior two months. Some contacts attributed the boost to rising demand coming from the retail sector and areas affected by Hurricane Sandy. Freight executives were fairly positive in their outlook for 2013, with the caveat that a resolution is reached on issues involving fiscal policy. Costs associated with truck maintenance held steady, while diesel fuel prices fell. Reports on capital spending were mixed. Some freight haulers said that 2012 expenditures reached targeted levels. Others reported a postponement in purchasing equipment for replacement and expansion due to a sluggish economy and supply issues related to Class 8 trucks. Spending in 2013 is expected to be similar to 2012 levels, and it will be mainly for replacement. Due to uncertainty about the economy, hiring plans for 2013 are tentative. Wage pressures were contained. 


\section{FIFTH DISTRICT-RICHMOND}

Overview. District economic activity generally grew at a modest pace in recent weeks. District manufacturing growth slowed, and retail sales flattened, with the exception of food and vehicle sales. Non-retail services providers reported stable to stronger demand, and tourism activity was at normal winter levels. Commercial and consumer lending varied by location, while the environment remained competitive. Residential real estate activity continued to improve; reports on commercial real estate activity, however, were mixed. Agricultural conditions remained favorable. Oil and natural gas production held steady at high levels during the past six weeks, but coal production fell. Labor market conditions weakened somewhat since our last report. Manufacturers' input prices were little changed, while finished goods prices rose at a slower rate, and the pace of wage growth remained moderate. Services providers' prices rose slightly faster and non-retail wage growth edged up. Retail price increases slowed, and wages fell.

Manufacturing. District manufacturing continued to expand, but at a more modest pace since our last report. A furniture manufacturer said that his business had improved through gains in market share and new product introductions, and that the improvement should continue in 2013. A spokesperson for the technology industry reported that 2012 was expected to be flat, but instead grew by ten to twelve percent. Another contact stated that, "Manufacturing is hanging in there," noting that niche markets were doing best, but only if they were not dependent on international demand. A producer of lumber products commented that sales volumes and orders dropped, in part because of Hurricane Sandy's impact on their customer base in the northeast. An electrical components manufacturer reported that business was "terrible," adding that his only sales were to replace ruined equipment from Hurricane Sandy, and that export orders to Europe had dropped off. According to our latest survey, raw materials prices were relatively flat, while finished goods prices rose at a slightly slower pace.

Ports. The typical seasonal surge in import volumes shifted as a result of two major events. The first was the threat of an East Coast port strike that has loomed since the September 2012 expiration of the master contract between the International Longshoremen's Association and the U.S. Maritime Alliance. A number of shippers used alternative West Coast and Canadian ports ahead of the peak season to minimize disruptions to their businesses. Secondly, Hurricane Sandy caused diversions to Fifth District ports, boosting an already solid peak season. In addition, bulk fuel shipments that were diverted to the Northeast created "a pinch in supply" for companies located further south. Exports of resins for plastics, grains, forestry products and metal scrap were especially strong, with imports being led by beverages and retail goods. Both exports and imports of auto-related products were robust.

Retail. Retail sales flattened, with the exception of food and vehicle sales, according to most merchants contacted since our last report. Several blamed the lackluster sales on the federal government's 
failure to resolve its fiscal issues. Most retailers responding to a special poll indicated that they planned an equal amount of holiday discounting as a year ago. A West Virginia department store manager reported that sales were a little soft ahead of Christmas, while other retailers noted little change. In contrast, many grocers noted an uptick in revenues. Although big-ticket sales were weak overall, car sales rose by double-digit percentages in recent weeks. Federal fiscal indecision also pushed sales of heavy trucks, construction equipment, and buses at the end of 2012, ahead of the possible expiration of bonus depreciation. According to survey respondents, retail price growth slowed during the past month.

Services. Services firms reported stable to stronger demand since our last report. An executive at a national freight trucking firm indicated that revenues flattened in the District, while another trucking company reported that demand slowed slightly, although that company was able to improve its margins. Demand strengthened at telecommunications and engineering firms, and a contact in Washington, D.C. remarked that law firms see regulatory practice as a growth industry. During the week of Christmas and New Year's Day, the CDC reported that the flu had become widespread across the District. An executive at a North Carolina healthcare facility commented that the "flu season hit early and hard," more than doubling the average number of cases for that time of year. Non-retail services prices rose slightly faster in recent weeks, according to survey respondents.

Tourism activity was at normal winter levels in recent weeks, and rate changes were modest. In addition, a D.C. contact commented that restaurant bookings were brisk for holiday meals and events. An executive at a Virginia resort area said that his rentals were filled up for the week from Christmas through New Year's Day. A source on the outer banks of North Carolina reported somewhat less tourism activity, compared to a year ago because of lingering road problems caused by Hurricane Sandy.

Finance. Demand for both consumer and commercial loans varied across the District. A North Carolina lender noted that mortgages for new purchases of homes declined, in part because of economic uncertainty. However, a second North Carolina lender said new financing is outpacing refinancing at his bank. According to another North Carolina banker, the home mortgage business is improving and he indicated that refinancing has strengthened in his region; in addition, a number of lenders stated that the competition among lenders for refinancing business has been aggressive. Finally, a banking contact with several locations in the District reported that demand for consumer loans and mortgages had not changed much. Bankers in Maryland and West Virginia reported that foreclosures have slowed. A West Virginia banker said that while overall credit quality has been very good, residential mortgage delinquencies have crept up slightly, and that demand for commercial credit had been steady at a relative high rate in recent weeks. Another West Virginia banker remarked that his region's commercial and industrial loan demand had slowed because economic progress has been "lumpy." A banker in North Carolina reported that loan demand from businesses had remained weak despite lower borrowing rates, owing in part to economic uncertainty. 
Real Estate. Residential real estate activity continued to improve since our last report. A contact in South Carolina said that the real estate market was dynamic in the Charleston area and that demand and pricing were stronger than they had been in a long time. A Realtor in the Washington, D.C. area expects a strong market through early 2013, as the combination of record low inventory and low interest rates encourages new listings. A contact in West Virginia told us that home sales in his area have improved considerably and that prices were flat for the first time since the drop in values two years ago. Another source saw improvement in the "move up" market but little to no activity in the speculative market. He also remarked that the start-up market for housing remained flat and that the effect of student loans on credit scores was a cloud over the mortgage market.

Reports were mixed on commercial real estate and construction markets in the District. While a few contacts reported modest improvement in activity since our last report, others noted flat activity or modest declines. A developer in the Carolinas said that absorption rates in the office sector tightened in the downtown Charlotte area, but vacancies in suburban areas remained elevated. In contrast, a real estate representative in Virginia indicated that office park absorption rates in the Roanoke suburbs were good, with ninety percent occupancy rates, which he attributed to new medical facilities. However, he noted that vacancies in the downtown area were considerably higher. Most sources also mentioned tightening of available office space, especially among Class A properties, due to lack of new construction. A Charlotte Realtor stated that leasing rates in the industrial sector continued to decline this year and noted little new development in the retail sector. Moreover, several realtors reported that rental rates were soft, noting that it was a "tenant's market." However, all contacts were in agreement that concessions were decreasing.

Agriculture and Natural Resources. Agricultural conditions remained favorable. Oil and natural gas production remained at high levels during the past six weeks. December was relatively mild across most of the District, with warmer than normal temperatures and significant precipitation. Small grain conditions improved with the added moisture, as did pastures and hayfields.

Although conventional oil and natural gas production held steady at high levels, the rig count fell in West Virginia. Cushioning the fall, many companies continued to drill in order to get wells in place before permits expired. In contrast, coal production fell last year due to lower demand from domestic utilities and offshore customers, idling many mines. One coal producer attributed the depressed coal market to stricter regulations coupled with lower natural gas prices, as well as a weaker economy both in the United States and in Europe.

Labor Markets. Conditions in labor markets weakened since our last report. There were several reports of soft demand for workers in part because businesses were reluctant to hire in the politically uncertain climate. Retail employment dropped sharply in recent weeks, and several service sector contacts indicated that hiring decisions were in a holding pattern. Exceptions were to fill vacated positions and to ease nursing shortages, and a Washington contact remarked that restaurants were paying bonuses to 


\section{$\mathrm{V}-4$}

attract managers. Sources continued to report difficulty finding qualified workers to fill vacancies, particularly in advanced manufacturing. Two Virginia temporary employment agencies noted increased demand for high tech and highly skilled workers. According to an ad hoc poll, less than half of the retailers who made seasonal hires expected to offer those employees a permanent position after the holidays. Wage growth in manufacturing remained moderate, even among skilled workers, while average retail wages declined. In contrast, non-retail service sector wages continued to rise at a moderate pace. 


\section{SIXTH DISTRICT - ATLANTA}

Summary. Reports from Sixth District business contacts indicated that economic activity expanded moderately in late November and December, with most expecting continued modest growth in early 2013.

District merchants cited mildly positive holiday sales, while tourism contacts noted continued strength in both business and leisure travel. Residential real estate contacts experienced ongoing modest sales growth for both new and existing homes on a year-over-year basis, while commercial contacts described demand conditions as improving, especially in the multifamily segment of the market. Manufacturers, on the other hand, noted a decline in orders and production. Reports from bankers indicated that loan demand had strengthened, driven in large part by an increase in mortgage lending. Employment levels across the District expanded at a modest pace, while pricing pressures remained subdued.

Consumer Spending and Tourism. District contacts reported cautious optimism following a robust start to the holiday season. While sales were better than expected over the Thanksgiving weekend, reports covering the entire holiday season showed that total sales, although above yearago results, did not appear to meet expectations. Deep discounting was prevalent throughout the holiday season. Auto sales remained robust and truck sales were somewhat positive with sales of replacement vehicles driving the growth for that segment.

Travel and tourism contacts continued to report strong activity. Hospitality contacts noted increases in visitation and spending in the final quarter of 2012. Lower gasoline prices boosted leisure travel. Business travel and attendance at major conventions also increased. International visitors continued to lift tourism activity and advance reservations of international travel have exceeded expectations. The outlook for 2013 remained positive with hospitality contacts projecting increases in occupancy rates and revenue per available room.

Real Estate and Construction. The majority of District residential brokers reported that recent existing home sales were ahead of year earlier levels. Sales growth was strongest in Florida. Most brokers in the region again noted declining inventories and rising home prices. Buyer traffic remained ahead of the year-ago level by most accounts. For 2013, most anticipate home sales growth will continue to improve slowly.

Reports from District homebuilders were a bit more positive than in our last report. Builders reported that recent new home sales and construction activity were slightly ahead of year-earlier levels. The majority of builders continued to report that new home inventories were below the yearago level and prices were up slightly. Buyer interest remained strong but several builders continued 
to note difficulty securing development and construction financing. Despite the challenges, the outlook for construction activity remained positive and builders anticipate new home sales in 2013 to exceed 2012 levels across many parts of the District.

Reports from District commercial contractors indicated that the pace of construction activity improved modestly from the third to fourth quarter and was ahead of the previous year's performance. Apartment development was particularly strong. The pipeline for commercial construction at the end of the fourth quarter was greater than the year-ago level by most accounts. Most said that commercial construction development financing remained scarce. However, the outlook for 2013 remained positive as most contacts expect commercial construction activity to be slightly ahead of 2012 levels. Commercial brokers indicated that most office, industrial, and retail markets in the District experienced modestly positive absorption rates. Overall, contacts continued to anticipate steady, but slow improvements in District commercial real estate markets during 2013.

Manufacturing and Transportation. Manufacturing contacts in the region reported that new orders and production contracted in December. Finished inventory levels also declined from the previous month. However, nearly half of manufacturing contacts expect production to be higher than current levels over the next three-to-six months, up from just under one-third in November.

Trucking contacts reported a notable increase in tonnage in November, representing the first gain since July 2012, and offsetting a drop in October's readings. Reports suggested that Hurricane Sandy affected both months' readings. A large truck dealer reported it is expanding sales to include flatbed trailers in response to anticipated increased movement of construction materials as a result of improvements in the housing sector. Railroad contacts reported an increase in total carloads in November over year-ago levels with the largest increases occurring in chemicals and agricultural products while declines were noted in coal, metallic ores, and metals. Concerns grew over low river levels that have led to delays in Mississippi River barge traffic.

Banking and Finance. Many banking contacts indicated loan demand had increased and they've added lending specialists to deal with current and anticipated demand. Competition for quality borrowers remained fierce and there was some indication that banks were more willing to increase their tolerance for risk. Auto lending remained active and some depository institutions noted more loan growth in November and December. Low rates encouraged mortgage activity, and purchases accounted for a larger share of mortgage loans than in the recent past. Community banks reported spending a larger portion of their income on compliance and remained concerned about increasing regulatory pressures. 
Employment and Prices. Since the last report, payroll growth increased mildly across the District, though contacts said that uncertainty over fiscal policy and healthcare costs tempered hiring decisions. Aggregate gains in job growth across the District were fueled largely by strong job growth in Florida and Louisiana. Contacts in Florida's leisure and hospitality industry reported moderately improved hiring expectations, while the construction, retail, and energy sectors in Louisiana saw relatively healthy increases in employment in November and December.

Pricing pressures remained subdued, according to results from our December Business Inflation Expectations survey which indicated that unit costs were up 1.5 percent over the past 12 months, which is down from 1.7 percent in November. Margins improved somewhat in December, especially for retail contacts who reported being able to pass on slightly higher markups compared to the holiday season in 2011. Looking forward, year-ahead unit cost expectations of businesses were 1.9 percent in December, moderating from 2.1 percent the month before. Businesses continued to cite costs relating to tax policy, regulation, and healthcare as sources of uncertainty going into 2013.

Natural Resources and Agriculture. Planned investments, ranging from reserve development to increased refining and petrochemical operations to new pipeline infrastructure, continued to take place in the energy sector. For example, preparation for development of a large gas-to-liquids (GTL) and ethane cracker complex in Louisiana was announced, which is expected to increase the region's production capacity for GTL diesel and ethylene. Separately, industry contacts maintained that higher margins for natural gas liquids and other associated products continued to warrant ongoing drilling in natural gas wells, despite low prices for natural gas. In the midst of an apparent surge in investment activity in the energy industry, District contacts continued to cite a shortage of specialized skilled labor as a significant hurdle facing expansion plans going forward.

Prices for corn, soybeans, beef, and poultry remained above year-ago levels, while the price for cotton was lower than this time last year. Dry conditions persisted in much of the District, although late December rains helped many areas in the region. 


\section{SEVENTH DISTRICT-CHICAGO}

Summary. Economic activity in the Seventh District continued to expand at a slow pace in late November and December. Many contacts expected that growth in 2013 would match or outperform 2012, but some remained more cautious than others, citing the impact of continued uncertainty over federal fiscal policy on the near-term economic outlook. Consumer spending increased somewhat, while growth in business spending remained tepid. Growth in manufacturing production was again moderate. Residential construction continued to increase at a slow but steady pace, but nonresidential construction remained weak. Credit conditions continued to improve gradually. Cost pressures eased some, and wage pressures remained moderate. Cattle and hog prices moved higher; while corn, soybean, and milk prices moved lower.

Consumer spending. Consumer spending increased somewhat from the previous reporting period. Retailers noted that holiday sales were slightly below expectations. Multiple retailers reported that store traffic volumes fluctuated more throughout the holiday season than in recent years. Apparel and jewelry sales were strong, while sales of toys and electronics were more in line with expectations, and general merchandise sales were weaker. Auto sales in the District lagged the national pace, with several dealers indicating that lower consumer confidence hurt year-end sales. Some auto dealers also noted that inventory levels were slightly high. However, dealers expected new car sales to be stronger in 2013 due to pent-up consumer demand, easing credit conditions, and rising used vehicle prices.

Business spending. Growth in business spending remained tepid in late November and December. Inventory investment was little changed while spending on equipment and structures continued to slowly increase. Some contacts again noted a reluctance to spend given heightened uncertainty related to federal fiscal policy. Labor market conditions were unchanged. Hiring plans for the coming year were limited. Retail employment increased with some seasonal hiring, but few significant full-time post-holiday additions were expected. A recruiting firm noted that customers that are heavily dependent upon government spending were very cautious about increasing headcount amidst the fiscal cliff negotiations. Companies with exposures to Europe were likewise being more conservative in their hiring plans. However, contacts indicated that there is still strong demand for talent in technology, engineering, accounting and finance, energy, and skilled manufacturing jobs. Manufacturers indicated a reluctance to reduce headcount despite the recent slowdown in activity, choosing to cut overtime hours instead in expectation of a rebound in 
production in the first quarter. In addition, some contacts are also beginning to limit hours for parttime workers to less than 30 hours in order to avoid the 30-hour (full-time employee status) rule related to the Affordable Care Act.

Construction/real estate. Construction and real estate activity was mixed in late November and December. Residential construction continued to rise. However, homebuilders noted that new construction would stay moderate in many regional markets as long as existing home prices remained well below new home prices. Existing home prices did edge up in some areas of the District, and rental rates continued to rise. In addition, contacts reported that in many cases credit for homebuyers remained tight, slowing the pace of home sales. Demand for nonresidential construction remained weak, but some improvement was noted in the light industrial and office markets. Several commercial real estate contacts observed that uncertainty surrounding federal fiscal policy continues to weigh on structures spending in a number of market segments. However, commercial real estate conditions improved slightly. Vacancy rates continued to decrease; and while the pace of leasing and acquisition deals remained slow, it picked up slightly as financing became easier to obtain.

Manufacturing. Growth in manufacturing production continued to be moderate over the reporting period. Capacity utilization in the steel industry increased slightly and service center inventories were noted to be at desirable levels. Specialty metal manufacturers reported a decline in quoting and new orders as customers continued to delay purchases until the last minute. In contrast, a contact in the defense industry noted a substantial rebound in orders due to the two-month delay in sequestration. Contacts noted a slight pick-up in demand for construction equipment due to improvement in the housing market, although demand from the public sector remained weak. The auto industry remained a source of strength for manufacturing. Auto suppliers reported strong orders through the end of the year, and many expected vehicle production to expand in 2013. Activity in the energy industry appeared to slow. The lower price of natural gas, in part due to abundant supply, has negatively affected coal mining. In addition, one contact noted the lower prices had also led to a pause in shale gas production. However, contacts expected activity in the energy industry to rebound in early 2013.

Banking/finance. Credit conditions continued to gradually ease over the reporting period. Credit spreads and financial market volatility remained low, and asset quality continued to improve. Credit line utilization rose substantially, with contacts citing end-of-year factors such as tax planning and special dividends as reasons for the increase. Banking contacts also reported moderate 
growth in demand for small business loans, particularly from manufacturing industries such as machining and packaging. Pricing for business loans changed little, while contacts cited some loosening of loan standards. Consumer loan demand, particularly for mortgage and auto loans, continued to increase. Contacts indicated, however, that less home refinancing activity was being processed than in the previous reporting period.

Prices/costs. Cost pressures eased in late November and December. Most raw material prices moved lower, although there was some pressure on lumber and drywall prices and concerns remained around potential food and energy price increases. In contrast, manufacturers supplying the defense industry said their customers were attempting to negotiate large price decreases; these contacts thought they could instead secure multi-year price agreements in exchange for more moderate price reductions. A contact in the grocery industry indicated that they have been unable to fully pass on recent meat and milk cost increases. More generally, retailers reported that discounting and promotions increased over the holiday shopping season. Wage pressures remained moderate, but nonwage costs increased. Contacts again cited higher healthcare costs; however, a few noted that increases this year were less pronounced than a year ago. Several contacts also reported increasing 401(k) payouts and year-end bonuses.

Agriculture. Although drought conditions eased, depleted soil moisture remained a concern in much of the District. The low levels of the Mississippi River hampered barge traffic moving both crops to market and inputs to farms. Crop operations tended to come out ahead for the year if they had adequate insurance coverage, and most crop farmers saw their net worth grow. Uncertainty regarding the tax treatment of capital expenditures led farmers to move up purchases of equipment and other capital improvements into 2012. Corn and soybean prices slid during the reporting period. Milk prices decreased, while cattle and hog prices increased. Of these agricultural products, only hog prices were below the levels of a year ago. Farmland values trended higher, with an extra spurt of farm sales at the end of 2012 in anticipation of tax code changes. Cash rents for cropland increased as well for the upcoming season. 
VIII-1

\section{Eighth District - St. Louis}

\section{Summary}

The economy of the Eighth District has grown at a modest pace since our previous report. Recent reports of planned activity from service firms have been positive. In contrast, reports of planned activity from manufacturing firms have been negative on net. Residential real estate market conditions have continued to improve, and commercial and industrial real estate conditions have also improved in some areas. Total lending at a sample of small and mid-sized District banks decreased slightly from early September to mid-December. Agricultural conditions in the District have been mixed since our previous report.

\section{Manufacturing and Other Business Activity}

Reports of plans for manufacturing activity have been negative on net since our previous report. Several manufacturing firms reported plans to lay off workers and close plants in the Eighth District, while fewer manufacturing firms reported plans to hire new workers or expand operations. Firms in HVAC equipment, electric components, food, and automobile parts manufacturing reported plans to lay off workers. In contrast, firms that manufacture small arms and medical devices reported plans to hire new workers and expand operations.

Reports of planned activity in the District's service sector have been positive since our previous report. Firms in electric power generation, food services, business support services, and information services announced plans to hire new employees and construct new facilities. In contrast, firms in medical services and in financial services reported plans to lay off workers. Retail contacts in Louisville reported the opening of several new facilities, and an auto dealer group is expanding operations in the Memphis area. Retailers in Memphis reported increased 


\section{VIII-2}

sales on an annual basis, and auto dealers in Little Rock and Louisville also reported increased sales for the year.

\section{Real Estate and Construction}

Home sales increased throughout most of the Eighth District on a year-over-year basis. Compared with the same period in 2011, November 2012 year-to-date home sales were up 16 percent in Louisville, 5 percent in Little Rock, 13 percent in Memphis, and 19 percent in St. Louis. Residential construction increased in the majority of the District. November 2012 year-to-date single-family housing permits increased in the majority of the District's metropolitan areas compared with the same period in 2011. Permits increased 40 percent in Louisville, 26 percent in Little Rock, 30 percent in Memphis, and 25 percent in St. Louis.

Commercial and industrial real estate market conditions have improved in some areas of the District. Contacts in the Memphis metropolitan area noted that commercial and industrial real estate activity remained stable. A contact in St. Louis noted that office space leasing activity improved in the downtown area, while a contact in Louisville noted strong suburban office space leasing activity. Commercial and industrial construction activity continued to improve throughout most of the District. Contacts in Louisville noted plans for speculative industrial construction in Jefferson County, Indiana, and several industrial construction projects in southern Indiana and in Bullitt County, Kentucky. A contact in Little Rock reported new commercial construction projects in southwest Little Rock. Contacts in Memphis reported a number of ongoing health care construction projects in the downtown area. A contact in St. Louis reported commercial construction plans in the Dogtown neighborhood and that an automobile assembly plant expansion is under construction in Wentzville. 


\section{VIII-3}

\section{Banking and Finance}

Total loans outstanding at a sample of small and mid-sized District banks decreased 0.6 percent from early September to mid-December. Real estate lending, accounting for 72.4 percent of total loans, was little changed. Commercial and industrial loans, accounting for 15.7 percent of total loans, decreased 4.4 percent. Loans to individuals, accounting for 4.7 percent of total loans, were essentially unchanged. All other loans, accounting for 7.1 percent of total loans, increased 1.7 percent. During this period, total deposits at these banks decreased 0.6 percent.

\section{Agriculture and Natural Resources}

November year-to-date commercial red meat production across the District's states was 4.3 percent higher in 2012 than the same period in 2011. By contrast, November year-to-date poultry production as measured by the number of young chickens slaughtered was down 2.2 percent relative to 2011. The District's states ginned 6.4 percent less cotton from January 1 to December 15, 2012, compared with the same period in 2011. Year-to-date coal production in the District's states (excluding eastern Kentucky) at the end of November 2012 was 9.4 percent higher than the same period in 2011, while coal production for November 2012 was roughly on par with production for November 2011. 


\section{NINTH DISTRICT--MINNEAPOLIS}

The Ninth District economy grew moderately since the last report. Increased activity was noted in consumer spending, tourism, professional services, manufacturing and energy. Construction and real estate experienced continued strong recovery. Activity was steady in agriculture and slowed slightly in the mining sector. Labor markets tightened modestly. Wage increases were moderate. Overall price increases were subdued.

\section{Consumer Spending and Tourism}

Overall consumer spending was up slightly relative to a year ago. The holiday shopping season was somewhat stronger than last year, with bigger gains in North Dakota and Montana. Same-store sales at a Minnesota-based retailer were flat in December compared with a year ago. A Minneapolis area mall reported that holiday traffic was level from a year ago, but sales were up. Activity at a shopping center in South Dakota was relatively level from a year earlier. A North Dakota mall manager reported that December sales were about 10 percent higher than last year; jewelry sales were particularly strong. Retailers in the Great Falls, Mont., area generally reported a solid holiday season. According to the Minneapolis Fed's business outlook survey, 30 percent of respondents expect increases in consumer spending in their communities during 2013; 25 percent expect decreases. These results were similar to last year's survey.

Recent new car and truck registrations in Minnesota were higher than a year ago. In Montana, vehicle sales remained steady during the past few months, according to a representative of an auto dealers association.

Winter tourism activity was strong in areas with snow, but lackluster in dry areas. A Montana ski resort reported that visits were up and reservations were looking good for the rest of the winter. However, in the Upper Peninsula of Michigan, activity was soft due to marginal snow conditions. The winter tourism season got off to a slow start because of a lack of snow in western South Dakota; recent snowfall should help spur activity, according to an official.

\section{Construction and Real Estate}

Commercial construction activity increased at a solid pace since the last report. The permitted value of new commercial construction in December was up 26 percent in Sioux Falls, S.D., and the value of November permits more than doubled in Billings, Mont. A major outlet mall is planned for the Minneapolis-St. Paul area. Residential construction increased considerably from a year ago. The value of November residential building 
permits in Billings was up 70 percent from last year, and the value of December permits in Sioux Falls was up 39 percent from a year ago. In the Minneapolis-St. Paul area, December residential permits were up 17 percent compared with December 2011.

Commercial real estate markets continued to tighten. A major commercial real estate firm forecast that Minneapolis-St. Paul area office vacancy rates will dip to 17.7 percent at the end of 2012 compared with 19.1 percent at the end of 2011. The same firm forecast industrial vacancy rates to drop to 9.9 percent from 11.2 percent. Residential real estate market activity increased. Home sales in November were up 20 percent from the same period a year ago in the Minneapolis-St. Paul area; the inventory of homes for sale was down 29 percent, and median sale prices rose 17 percent. In the Sioux Falls area, November home sales were up 20 percent, inventory was down 14 percent and the median sale price increased 9 percent relative to a year earlier.

\section{Services}

Activity at professional business services firms grew since the last report. Services sector respondents to the business outlook poll expect sales volumes and capital investment at their firms to grow in 2013. An appraisal company noted that demand is increasing for its services, and the backlog continues to increase. Another appraiser noted, "I am turning down more business than I am accepting."

\section{Manufacturing}

District manufacturing increased slightly since the last report. According to a December survey of purchasing managers by Creighton University (Omaha, Neb.), manufacturing activity increased in Minnesota and South Dakota after five consecutive months of decreases. Activity also increased in North Dakota, but at a slower pace than in recent months. The Minneapolis Fed's 2012 survey of manufacturers indicated that respondents on average expect orders, production, employment and profits at their operations to increase in the coming year. The outlook for capital investment was flat. A company announced that it is opening a 40,000-square-foot cereal ingredient processing facility in South Dakota.

\section{Energy and Mining}

Activity in the energy sector continued to grow, while mining slowed. District oil production remained at record levels. An oil refinery in Minnesota announced plans for a $\$ 400$ million upgrade in order to process more oil. Late-December oil and gas exploration activity decreased slightly in North Dakota and increased in Montana from the previous month. A railroad put on hold its plans to expand a coal-shipping line from Wyoming, 
citing a weaker outlook for domestic coal. Iron ore production remained strong in northern Minnesota; however, recent months were down from levels earlier in 2012. A large mining company announced that it will idle some of its production at operations in Minnesota and the Upper Peninsula in 2013, citing lower ore prices and reduced global demand. A mining company increased its estimate of deposits at a potential copper, nickel and precious metals mine in northern Minnesota.

\section{Agriculture}

Agriculture was steady at high levels. Crop prices came down somewhat recently but remain relatively high, a slight relief to livestock and dairy producers who have been hammered by high feed costs. The selloff of livestock herds continued. Sugarbeet producers in Minnesota and North Dakota saw a record crop in 2012, but prices were down. Prices received by farmers increased in December from a year earlier for corn, wheat, soybeans, chicken, dairy products and cattle. Prices for hogs, turkey, eggs and dry beans decreased. According to the Minneapolis Fed's third-quarter (October) survey of agricultural credit conditions, farmland prices continued their rapid rate of increase.

\section{Employment, Wages and Prices}

Labor markets tightened modestly since the last report. A manufacturer in Minnesota recently announced plans to open a new facility that would employ 400 new workers. Up to 300 employees are expected to eventually work at a call center in Minnesota. However, an iron ore plant idled 125 workers, and a high tech company laid off over 40 employees in Minnesota due to a slowing in demand. According to respondents to the business outlook poll, 28 percent expect to increase hiring during 2013, while 15 percent expect to decrease staff, similar to last year's poll.

Wage increases were moderate. According to the business outlook poll, 93 percent of respondents expect wages in 2013 to increase no more than 3 percent. Business contacts in South Dakota and Montana expected to generally increase wages between 2 percent and 3 percent in 2013 from a year earlier. However, wage increases in the oil-drilling areas of North Dakota and Montana are expected to be higher.

Overall price increases were subdued. Minnesota gasoline prices at the end of December were down about 20 cents per gallon since the end of November and were about 10 cents per gallon less than a year ago. A Minnesota-based food maker said it expects ingredient cost inflation of up to 3 percent. Some metals prices increased since 
mid-November. According to the survey of manufacturers, 37 percent of respondents expect to increase selling prices in 2013, while 16 percent expect to decrease prices. 


\section{TENTH DISTRICT - KANSAS CITY}

The Tenth District economy expanded modestly in November and December. After a strong start to holiday shopping, retail sales remained solid as the holiday season progressed and vehicle sales remained higher than a year ago. Manufacturing activity, while above year-ago levels, eased further, especially in the non-durable goods sector. Although energy activity remained historically high, both oil and natural gas rig counts dropped and District contacts expected further declines in the coming months. Residential and commercial real estate markets strengthened as prices and sales trended up and inventories declined. Bankers also reported strong demand for both residential and commercial real estate loans. Historically high crop prices supported crop sector incomes, and livestock profits improved with an uptick in livestock prices. Wage pressures remained subdued except for the ongoing need to fill specialized positions in energy, high-tech, transportation, and construction industries. Numerous business contacts noted they were delaying hiring plans due to economic uncertainty associated with the fiscal cliff and potential policy changes.

Consumer Spending. Consumer spending edged up in November and December, and sales expectations softened heading into the new year. Retail sales rose since the last survey period but retailers expected less growth after the holiday season. Several store owners noted that lower-priced items and home furnishings sold particularly well while sales of high-end items remained sluggish. Auto sales slowed but remained higher than a year ago and some dealers noted undesirably high inventory levels. Near-term sales expectations also eased but generally remained positive. Hotel traffic fell sharply and occupancy rates were substantially below last year's levels. Although tourist activity picked up somewhat, visitor counts remained well below a year ago and were not expected to improve in the near-term. Despite slightly better sales and higher selling prices, restaurant owners turned pessimistic about future sales growth as food costs mounted. Numerous contacts pinned their less positive outlook for future growth on uncertainty associated with the fiscal cliff that was inhibiting consumer spending.

Manufacturing and Other Business Activity. Manufacturing activity eased since the last survey period, particularly in the non-durable goods sector. Factory production retreated to year-ago levels after a more pronounced contraction in non-durable goods activity trimmed 
production over the past month. The relative strength of durable goods activity was supported by the production and sales of electrical equipment, appliances, and components. Manufacturers expected generally stronger activity over the next six months. Factory managers at non-durable goods plants, however, were more optimistic about future activity than their peers at durable goods plants with stronger expectations for production, shipments, and new orders over the next six months. Despite a potential rebound in manufacturing activity, factory employment was not expected to rise, with some manufacturers noting that they were delaying hiring plans because of uncertainty in tax and regulatory policies. High-tech service firms expected robust sales and capital spending over the next three months. With railroad traffic continuing to rise and flat sales expectations at transportation service firms, backlogs and capital spending remained solid.

Real Estate and Construction. Residential and commercial real estate sales accelerated since the last survey period despite some weakness in new residential construction. Persistently strong sales of existing residential homes drove prices higher as home inventories continued to fall. Real estate contacts noted that low- to mid-priced homes continued to sell well. Overall mortgage activity and refinancings remained higher than a year ago although expectations for the coming months edged down. Despite recent strength at construction supply firms, sales deteriorated unexpectedly over the past month due partly to higher selling prices. Builders noted that surging lumber and drywall costs led to fewer housing starts in November and December. Commercial real estate markets also improved substantially since the last survey period. Vacancy rates continued to fall with a notable improvement in sales, absorption, and rents, although some contacts noted that economic uncertainty hindered activity. Rising commercial real estate prices were expected to persist in the coming months, but contacts expected a slower pace of both sales activity and absorptions.

Banking. Bankers, on average, reported stronger loan demand, improved loan quality, and higher deposit levels in the recent survey period. Overall loan demand continued to strengthen, led by demand for residential and commercial real estate loans. Respondents also reported stable loan demand for both commercial and industrial loans and consumer installment loans. Interest rates on commercial and industrial loans continued to edge lower. Most bankers reported improved loan quality compared to a year ago, and they also expected the outlook for loan quality to continue improving over the next six months. Credit standards remained largely 
unchanged in all major loan categories and respondents also reported generally higher deposit levels since the last survey period.

Agriculture. Drought continued to impact crop conditions and livestock profits improved with higher livestock prices and lower feed costs. District winter wheat conditions remained relatively poor due to persistent drought. The drought also caused water levels on the Mississippi River to fall further, hindering commodity transportation to and from agricultural regions. Still net farm incomes remained high due to historically high crop prices and crop insurance payments. Livestock profit margins also improved over the past six weeks due to a post-harvest decline in crop prices and rising livestock prices. District contacts noted a surge in land sales, sparked by concerns of tax policy changes in the new year.

Energy. District energy activity contracted in November and December and was expected to slow further in the coming months. The number of active oil rigs in the District eased from the previous survey period despite a year-end uptick in crude oil prices. The number of active natural gas rigs declined as high supplies of natural gas in storage kept prices from rising due to winter heating needs. Energy contacts expected steady demand to stabilize oil prices and the current oversupply of natural gas to push prices lower. Wyoming's coal output dropped in December and annual production fell moderately short of year-ago levels. District ethanol production remained steady and profit margins, while still poor, improved slightly with easing corn prices.

Wages and Prices. Although wage pressures remained subdued during the survey period, raw materials prices rose further and more companies expected to raise finished goods prices in the coming months. Many businesses reported delaying hiring due to uncertainty surrounding the fiscal cliff and health care policy. Yet, some firms were offering wage premiums to fill specialized positions, particularly in the energy, high-tech, transportation, and construction industries. Raw material costs at factories climbed higher, and more factories planned to raise finished goods prices over the next six months. Builders expected higher prices for many construction materials, particularly lumber and drywall, to continue climbing due to tight supplies. After rising during the holiday shopping season, retailers expected retail prices to flatten during the coming months. Restaurant owners planned to increase menu prices due to high food costs. In contrast, fewer bookings led hotel operators to reduce average room rates. 


\section{ELEVENTH DISTRICT—DALLAS}

The Eleventh District economy expanded at a modest pace over the past six weeks. Reports on manufacturing activity remained mixed. Real estate and construction activity continued to improve. Retailers said holiday shopping boosted sales, and automobile dealers reported that sales were above year-ago levels. Staffing, accounting and legal services firms noted steady demand, while reports from transportation service firms were mixed, but improved overall. Energy activity remained at high levels despite a decline in the rig count, and financial firms reported modest growth in loan demand. Agricultural conditions remained dry. Prices were mostly stable, and wage pressures remained limited. Employment levels were steady to up. Many responding firms' outlooks reflected fiscal uncertainty during the reporting period.

Prices Most respondents noted stable prices, although accounting and legal services firms reported a modest rise in billing rates and some transportation service contacts noted an increase in freight charges. Overall, costs were flat to up during the reporting period. Some construction-related manufacturers and transportation service firms noted higher input costs. An aviation manufacturer said they planned to implement price increases this month due to rising input costs. Feed costs for livestock were at record high levels, while prices of other agricultural commodities declined slightly.

The price of WTI rose over $\$ 90$ per barrel during the reporting period. Natural gas prices remained depressed. On-highway diesel and gasoline prices trended down, and prices of petrochemical products were mixed.

Labor Market Employment held steady or increased at most responding firms. Reports of employment increases came from legal firms, auto dealers, and a few manufacturers. Retailers said employment was up from a year ago, and one contact reported difficulty in filling IT positions. Accounting firms reported hiring at a slower pace than the last report. Auto dealers noted difficulty finding qualified workers, and there were scattered reports of shortages of skilled workers at energyrelated firms. Wage pressures remained largely subdued, although airlines reported upward pressure and some construction-related manufacturers reported plans to give cost of living adjustments in January.

Manufacturing Construction related manufacturers' reports were mixed. Lumber producers noted stronger sales due to strong single-family construction, but demand for other products remained the same or softened since the last report. Outlooks were uncertain, with some responding firms putting off major decisions until the fiscal cliff was resolved. Demand for fabricated metals also softened over the reporting period, although outlooks for 2013 were optimistic. Primary metals producers noted demand growth was slower than expected. 
Respondents in high-tech manufacturing said that production and orders were flat to slightly down. One respondent noted that the weak global economy was slowing demand across a broad array of information technology products. Contacts said customer inventories were lean, while producer inventories had increased slightly but remained near desired levels. Respondents' outlooks for the next three to six months were more uncertain than at the time of the last report. Most said that they are planning for weakness to continue, and that they may reduce employment levels in 2013.

Demand for paper products was strong in the first part of the reporting period but stalled in recent weeks, in line with normal seasonal patterns. Contacts were more pessimistic in their outlooks, however, due to uncertainty regarding fiscal issues. Food demand increased due to a seasonal pickup, and the outlook was positive among contacts.

Overall, transportation manufacturing contacts said demand was mostly flat to up slightly. Automobile manufacturers said business was up, and outlooks were more optimistic. Demand for aviation equipment increased, but remained below year ago-levels.

Petrochemicals producers noted Gulf Coast chemical production was up compared with last year. Gulf Coast refineries were operating at rates above 90 percent, and margins remained healthy. Refiners said that despite sluggish domestic demand for distillates, strong export demand has kept inventories from building.

Retail Sales Retail sales volumes increased since the last report, mainly due to holiday shopping, and contacts said demand was up year-over-year. According to two national retailers, Texas continued to outperform the nation. Contacts were cautiously optimistic in their outlook for 2013; the largest source of uncertainty among contacts was the fiscal cliff.

Reports on automobile sales were mixed over the past six weeks, but were generally positive. All contacts noted that demand was up from a year ago. Selling prices were unchanged since the last report, but manufacturers were offering many more incentives, making the final price to consumers lower. Uncertainty regarding fiscal issues, future taxes, and health care costs, has moderated firms' outlooks.

Nonfinancial Services Staffing services firms reported mixed results. Most said that demand held steady, while one said orders had softened slightly. Contacts continued to be very concerned about new health care laws in 2014, and some noted their customers' outlooks were more uncertain due to fiscal concerns. Overall, staffing firms' outlooks were slightly more pessimistic than six weeks ago.

Overall, accounting activity held steady with little growth; strong energy-related activity was the exception. Contacts expect modest growth in 2013. Legal firms reported steady demand. Transactions and wealth planning practices were reportedly the busiest they have ever been, energy-related activity remained strong, and real estate-related activity was better than expected. Responding firms remained optimistic in their outlooks. 
Reports from transportation services were mixed. Intermodal cargo volumes edged down seasonally and have slowed from early 2012, but container volumes increased during the reporting period. Railroads said cargo volumes remained steady despite extremely strong growth in energy-related shipments. Grain and coal volumes remained weak spots during the reporting period, but auto shipments increased despite a strike at the Port of Los Angeles that disrupted the flow of containers. Shipping companies said that small parcel volumes posted very strong growth since the last report, particularly due to retail activity. Air cargo volumes were up slightly in preparation for the holiday season. Airline contacts said that passenger demand was soft over the past six weeks. Outlooks from transportation services firms continued to reflect global economic uncertainty, and most firms expect weak growth in the near-term.

Construction and Real Estate Contacts in the single-family housing sector reported continued improvement in new and existing home sales. Despite increased construction activity housing inventories remain low, pushing overall prices up. Firms remain cautiously optimistic in their outlooks. Apartment demand continued to ease slightly overall, although occupancy rates remain historically high.

Demand for office and industrial space increased since the last report, according to contacts in the commercial real estate sector. Most firms expect to see an increase in nonresidential construction in 2013. Commercial property investment activity picked up slightly near year-end, and most respondents were fairly optimistic in their outlooks for 2013.

Financial Services Financial institutions reported modest growth in overall lending activity. The increase in corporate loan demand was mostly driven by customers opting to make purchases before year-end due to tax uncertainty, but there was also moderate growth in real estate lending activity. Consumer lending improved, with modest growth in mortgage and new automobile loan demand. Loan pricing remained extremely competitive, and deposits continued to grow despite very low rates. Firms' outlooks remained positive, with fiscal and regulatory concerns posing downside risks.

Energy Respondents at energy-related service firms said activity remained at high levels, despite a larger-than-expected decline in the domestic rig count driven by low natural gas prices. Although oil prices remain at healthy enough levels to support current activity, price volatility is making some firms nervous about drilling in higher cost fields. Contacts expect overall activity to be flat this year relative to fourth quarter of 2012, with some improvement expected in the second half of 2013.

Agriculture With little rainfall, most of the District remained in drought conditions since the last report. The drought is negatively impacting the winter wheat crop, and contacts are beginning to express concern for spring planting. Wheat harvest was mostly completed over the last six weeks, and production was up from 2011, mainly because the drought was less severe. Contacts noted that fiscal cliff concerns and the lack of a farm bill are creating a great deal of uncertainty. 
XII - 1

\section{TWELFTH DISTRICT-SAN FRANCISCO}

\section{Summary}

Twelfth District economic activity expanded at a modest pace during the reporting period of midNovember through December. Upward price pressures were limited overall, and upward wage pressures were quite modest. Sales of retail items this holiday season were similar to or up slightly from last year, and most business and consumer services gained. District manufacturing activity was mixed across sectors but generally appeared to move up. Demand for agricultural products increased, and extraction activity rose for providers of energy resources. Housing demand trended up further, and conditions were largely stable for commercial real estate. Contacts from financial institutions reported that loan demand was unchanged or up somewhat, and credit quality improved.

\section{Wages and Prices}

Upward price pressures were limited on balance during the reporting period. Price movements for energy items were mixed: retail gasoline prices fell, and electricity prices rose in some areas. Prices for some intermediate materials used in the construction sector, such as drywall and steel rebar, ticked up, while log and pulp prices remained flat. Prices of grapes and nuts increased, and higher prices for grains and corn due to the drought earlier in the year boosted prices of grocery dairy and meat items. A restaurant chain reported menu price increases in the 2 to 3 percent range.

Contacts in most sectors reported that upward wage pressures were modest. Limited hiring plans and ready worker availability in most sectors and regions have held down increases in wages and compensation. However, wages increased for some information technology workers who possess advanced skills and are in low supply. The market for technically trained workers for the petroleum industry remains tight. A few contacts expect wage hikes in 2013 in response to the expiration of multiyear, company-wide salary freezes. Health-care benefit cost increases are expected to accelerate and outpace wage increases.

\section{Retail Trade and Services}

Retail sales were on a par with or up slightly from last year's holiday season, but generally did 
not meet vendors' expectations. Online retailers experienced more robust sales growth than traditional brick-and-mortar retailers. Inventories generally were at or near desired levels given the pace of sales, although some retailers reported having an excess of winter apparel due to relatively mild weather conditions, while others ran short on certain consumer technology products. Contacts in the information technology sector indicated strong sales of newer hardware and games, but relatively weak sales of established goods as well as some Internet and digital media products. Both sales and margins were soft for grocers. New automobile sales remained solid, running well above levels from 12 months earlier, with year-end gains expected to be sizeable.

Demand for most business and consumer services rose. Contacts pointed to solid sales of various technology services, due mostly to typical year-end business spending increases. Revenues continued to expand for food service providers. Tourism and travel activity in the District was robust, with strong growth of visitor counts and spending reported in both Hawaii and Southern California. However, demand for health-care services remained relatively weak, with some reports of consumers continuing to opt out of elective procedures and health-care providers having excess capacity.

\section{Manufacturing}

District manufacturing activity was mixed across sectors but expanded overall during the reporting period of mid-November through December. With healthy demand for fuel efficient planes and a sustained backlog of orders, production activity for commercial aircraft and parts has been running well above levels from last year. Demand continued to grow at a modest pace for pharmaceutical and wood product manufacturers. By contrast, capacity utilization remained relatively low for manufacturers of technology equipment, and defense manufacturers have been trimming payrolls due to expected federal spending reductions. While demand for scrap metal remained somewhat weak by historical standards, that for steel products used in automotive manufacturing and in infrastructure and nonresidential construction improved. Contacts indicated that production activity picked up at petroleum refineries.

\section{Agriculture and Resource-related Industries}

Agricultural output gained further, and extraction activity of natural resources used for energy 
production continued to expand. Demand for most crop and livestock products continued to advance and was met in part through more intensive use of capital equipment. Extraction activity expanded on balance for petroleum and natural gas, and natural gas inventories remained at historically high levels.

\section{Real Estate and Construction}

Housing demand in the District strengthened further, while demand for commercial real estate was largely stable. Both prices and sales transactions of homes climbed in most areas, stimulating continued growth in home construction activity. In some regional markets, activity ratcheted up for higher-priced homes. Construction activity for multifamily residential projects grew further, in response to rising rents and tight availability of lower-priced homes. Demand for nonresidential space was largely stable. However, contacts reported that in select geographic areas of the District, substantial growth of technology firms has boosted demand for office space.

\section{Financial Institutions}

Contacts from financial institutions reported that loan demand was unchanged or up somewhat. Business loan demand was characterized as moderate. Banking contacts continued to highlight ample liquidity and generally stiff competition among lenders to provide credit to well-qualified business loan applicants, with community banks facing increasing competition from larger national banks for small business lending. Although owner-occupied commercial real estate financing is readily available, banks in most regions remain reluctant to lend to real estate investors outside of the multifamily residential sector. Contacts noted a slight slowdown in IPO, venture capital, and private equity activity in the District's technology, Internet, and digital media subsectors. Consumer lending expanded further, primarily for automobile purchases and new or refinanced home mortgages. Reports indicated that credit quality for both business and consumer loans has continued to improve, albeit at a slow pace. 